DOI: https://doi.org/10.31933/jimt.v2i4

Received: 4 Januari 2021, Revised: 20 Februari 2021, Publish: 13 Maret 2021

JIMT
JURNAL ILMU MANAJEMEN
TERANASI

\title{
FAKTOR-FAKTOR YANG MEMPENGARUHI PERSAINGAN DAN PERTUMBUHAN PASAR: BUDAYA, SOSIAL, PERSONAL (SUATU LITERATURE REVIEW)
}

\author{
Andreas Prasetia ${ }^{1}$ \\ ${ }^{1}$ Mahasiswa Magister Management Universita Mercu Buana, email: andreprans@yahoo.com
}

\begin{abstract}
Abstrak: Bisnis kecil dan menengah di Indonesia memiliki karakteristik yang berbeda dengan negara lain. Literature Review ini menguji pengaruh moderasi intensitas kompetisi dan pertumbuhan pasar terhadap hubungan faktor sosial, faktor budaya dan faktor personal. Budaya organisasi, faktor personal dan perorangan memiliki hubungan yang kuat dengan efektivitas organisasi. Ketiganya dapat memberikan dampak yang besar bagi masa depan organisasi. Dalam literature ini penulis akan mengulas persaingan dan pertumbuhan pasar baik pada pasar domestik maupun internasional. Berbagai aspek budaya, sosial dan personal telah ditemukan di beberapa penelitian tentang kaitannya dengan persaingan dan pertumbuhan pasar. Semuanya memiliki situasi yang sama dan harus menghadapinya untuk membuat kemajuan yang baik demi efektivitas perusahaan dalam bersaing di masa depan.
\end{abstract}

Keyword: persaingan pasar, pertumbuhan pasar, budaya, sosial, personal

\section{PENDAHULUAN}

Perubahan perubahan terjadi dalam lingkungan bisnis yang meliputi perubahan teknologi produksi dan teknologi informasi serta globalisasi mengakibatkan organisasi untuk terus berkembang dalam mencapai tujuan organisasi di tengah persaingan bisnis yang semakin ketat. Persaingan bisnis yang sangat ketat menuntut manajemen organisasi untuk menjamin usaha organisasi berjalan dengan baik, tetap bertahan dan terus berkembang. Salah satu agar manajemen untuk mencapai tersebut adalah menyusun, mengendalikan, melaksanakan dan mengevaluasi strategi pemasaran organisasi. Definisi sebuah pasar strategis, akan selalu memiliki fokus pada pasar potensial yang sesuai dengaan strategi perusahaan (Kotler, 2012). Tujuan dari penulisan "Literature Review Paper" ini adalah untuk lebih mamahami materi pada perkuliahan "STRATEGIC MARKETTING MANAGEMENT", sehingga dapat di implementasikan pada penulisan artikel ilmiah atau Tesis. "Literature Review Paper" ini mengkaji teori-teori dan artikel-artikel ilmiah dari jurnal-jurnal bereputasi yang bekaitan dengan tema-tema dari Rencana Pembelajaran Semester (RPS) yang berbasis Outcome Base 
Education(OBE) untuk menghasilkan kerangka konseptual (conceptual framework) untuk riset selnjutnya (tesis).

Secara rinci tujuan dari penulisan "Literature Review Paper" ini adalah mengetahui pengaruh atau hubungan antara variabel exogen $(\mathrm{X} 1, \mathrm{X} 2, \mathrm{X} 3$ dan $\mathrm{X} 4)$ terhadap variabel endogen (Y1 \& Y2):

1) Pengaruh atau hubungan faktor budaya terhadap persaingan pasar

2) Pengaruh atau hubungan faktor sosial terhadap persaingan pasar

3) Pengaruh atau hubungan faktor personal terhadap persaingan si pasar

4) Pengaruh atau hubungan faktor budaya terhadap pertumbuhan pasar

5) Pengaruh atau hubungan faktor sosial terhadap pertumbuhan pasar

6) Pengaruh atau hubungan faktor personal terhadap pertumbuhan pasar

7) Pengaruh atau hubungan persaingan pasar terhadap pertumbuhan pasar

\section{KAJIAN PUSTAKA}

\section{Teori Persaingan / kompetisi Pasar}

Berdasarkan konsensus umum diketahui bahwa persaingan pasar suatu produk dalam suatu industri mempengaruhi keputusan manajerial dan oleh karena itu merupakan penentu penting dari profitabilitas perusahaan. Namun, ada sedikit kesepakatan tentang bagaimana persaingan tersebut mempengaruhi perilaku eksekutif atau insentif yang diberikan kepada manajer (Porter, 1990; Nickell, 1996).

Ketika persaingan meningkat, perusahaan memberikan insentif yang lebih lemah karena manajer secara implisit termotivasi untuk bekerja lebih keras. Misalnya, Hart (1983) menunjukkan bahwa persaingan yang lebih besar memberikan insentif manajerial implisit yang lebih kuat, karena pemain pasar tambahan membuat perusahaan mendapatkan informasi yang lebih baik dan dengan demikian lebih mampu mengevaluasi tindakan manajer. Demikian juga, Schmidt (1997) menunjukkan bahwa peningkatan persaingan meningkatkan kemungkinan likuidasi dan oleh karena itu insentif yang lebih besar bagi manajer, yang bekerja lebih keras untuk mempertahankan pekerjaan mereka.

Untuk menguji hubungan antara persaingan dan konsentrasi, pertimbangkan apa yang terjadi ketika produk dapat diganti dalam suatu industri meningkat. Ketika pergantian produk meningkat, begitu pula persaingan harga hal ini memaksa perusahaan yang kurang efisien yang tidak dapat menjaga biaya tetap rendah untuk keluar dari industri atau bergabung dengan perusahaan yang lebih efisien, dalam jangka panjang. Lebih lanjut, peningkatan persaingan ini dapat menghalangi perusahaan potensial memasuki industri. Akibatnya, industri berakhir dengan lebih sedikit perusahaan dan konsentrasi yang meningkat. Perusahaan yang tersisa menghadapi peningkatan permintaan untuk produksi dan karenanya memberikan manajer insentif yang lebih kuat untuk mengurangi biaya marjinal (Hotelling, 1929; Salop, 1979). 
Literatur manajemen strategis berpendapat bahwa perusahaan dapat mempertahankan keunggulan kompetitif mereka dengan memanfaatkan sumber daya dan kemampuan di mana mereka memiliki keunggulan komparatif (misalnya, Helfat dan Peteraf, 2003; Hooley et al., 2006; Peteraf, 1993; Wernerfelt, 1984, 1995). Dalam konteks liberalisasi perdagangan, perusahaan domestik memiliki keunggulan komparatif dibandingkan perusahaan asing dalam hubungannya dengan pemangku kepentingan lokal, sementara mungkin sulit bagi mereka untuk bersaing secara biaya. Oleh karena itu, penulis berpendapat bahwa domestic perusahaan dapat menanggapi meningkatnya persaingan luar negeri dengan memperkuat hubungan mereka dengan konsumen lokal, karyawan, dan pemangku kepentingan lainnya. Dalam artian, dengan meningkatkan inisiatif sosial dan lingkungan, perusahaan dapat membedakan diri dan membangun penghalang perdagangan "lunak" yang merugikan pesaing asing mereka(Flammer, 2014).

Terlepas dari pentingnya pemahaman kita tentang cara kerja persaingan dan implikasi kebijakan ekonominya, secara mengejutkan hanya ada sedikit makalah teoretis tentang subjek ini. Jensen dan Meckling (1976) berpendapat bahwa tingkat persaingan tidak berpengaruh apapun pada biaya agensi. Bagaimanapun, kelonggaran manajerial dinikmati oleh manajer perusahaan, bukan oleh pemiliknya. Oleh karena itu, pemilik monopoli memiliki kepentingan yang sama untuk mengurangi biaya keagenan seperti halnya pemilik perusahaan kompetitif, dan keduanya harus menawarkan skema insentif yang persis sama. Argumen ini mengabaikan, bagaimanapun, bahwa skema insentif yang optimal bergantung pada lingkungan di mana perusahaan beroperasi ( $\tilde{\mathrm{A}}, 2007)$

Sebagian besar literatur dimulai dari pengamatan bahwa persaingan menghasilkan informasi tambahan yang tidak tersedia dalam industri monopoli. Holmstrom (1982) dan Nalebuff dan Stiglitz (1983) menganalisis penggunaan evaluasi kinerja relatif. Jika jumlah pesaing di pasar meningkat, dan jika guncangan yang mempengaruhi biaya masing-masing perusahaan berkorelasi, maka peningkatan persaingan menghasilkan informasi tambahan yang dapat digunakan untuk mengurangi masalah bahaya moral. Sementara gaji pemilik meningkat jika dia dapat memanfaatkan informasi ini, efeknya pada upaya manajerial masih ambigu. Bergantung pada distribusi probabilitas yang mendasarinya, mungkin saja biaya penerapan tingkat upaya yang lebih rendah berkurang lebih dari biaya penerapan tingkat upaya yang lebih tinggi di mana manajer dapat didorong untuk bekerja lebih sedikit. Selanjutnya, performanya relative evaluasi mensyaratkan bahwa gaji manajer bergantung langsung pada kinerja manajer yang bersaing (Schmidt, 1997)

Lokasi pasar merupakan salah satu hal yang dianggap para pedagang sebagai penyebab terjadinya kompetisi pasar. Lokasi pasar berhubungan dengan kenyamanan konsumen, dan jarak pasar yang berada dekat dengan konsumen dianggap lebih nyaman bagi konsumen. Jarak antara toko tradisional dan lokasi toko modern yang berada dalam satu jangkauan pelayanan akan mempengaruhi preferensi konsumen dalam menentukan tempat berbelanja(Asribestari \& Setyono, 2013) 
Berdasarkan teori dan kajian sebelumnya dapat menunjukkan bahwa konsentrasi pasar yang tinggi dapat mencerminkan level persaingan pasar. Ketika pasar bervariasi dalam produk yang dapat diganti, konsentrasi yang tinggi mungkin menunjukkan persaingan yang ketat. Di sisi lain, ketika ukuran atau biaya masuk pasar bervariasi, konsentrasi yang lebih sedikit dapat menjadi indikasi persaingan yang ketat.

\section{Teori Pertumbuhan Pasar}

Berdasarkan matriks ekspansi produk-pasar Ansoff (1965) yang terkenal, diversifikasi hanya mewakili satu jenis strategi pertumbuhan. Strategi pertumbuhan lainnya adalah penetrasi pasar, pengembangan pasar dan pengembangan produk. Fokus pada diversifikasi bisa jadi karena itu mewakili bentuk yang paling ekstrim dari strategi pertumbuhan, sedangkan pengembangan produk atau pengembangan pasar dianggap lebih sebagai kontinum dari pengembangan perusahaan (Abell \& Hammond, 1979; Ansoff, 1965). Namun, untuk perusahaan kecil dan menengah, bahkan pengembangan produk atau pasar dapat dianggap sebagai penghentian pengembangan sebelumnya (cf. Barber, Metcalfe \& Porteous, 1991) khususnya, ketika konteksnya didefinisikan sebagai pilihan strategi pertumbuhan internasional.

Penggunaan teori berbasis sumber daya untuk memprediksi strategi pertumbuhan terdapat dua tradisi berbeda dapat diidentifikasi. Yang pertama berkaitan dengan aliran besar penelitian tentang strategi diversifikasi di tingkat strategi perusahaan, di mana perhatian difokuskan pada peran sumber daya perusahaan dalam menentukan batas-batas kegiatan perusahaan. Diversifikasi dilihat sebagai hasil dari kelebihan kapasitas dalam sumber daya yang memiliki banyak kegunaan dan yang menyebabkan kegagalan pasar (Peteraf, 1993, hal. 188). Sumber daya dipandang sebagai kekuatan pendorong untuk diversifikasi, sementara peluang pasar - meskipun disebutkan - kurang terfokus. Dalam studi empiris, berbagai jenis indeks diversifikasi berdasarkan S.I.C. Kode (Standar Klasifikasi Industri) digunakan sebagai variabel dependen, sedangkan variabel independen terdiri dari rasio keuangan yang berbeda dan ukuran tidak langsung yang digunakan untuk menangkap sumber daya fisik dan aset tidak berwujud. Diasumsikan bahwa perusahaan dengan sumber daya yang dapat digeneralisasikan atau fleksibel dapat melakukan diversifikasi secara luas, sedangkan perusahaan dengan sumber daya yang terspesialisasi atau tidak fleksibel akan mengikuti strategi diversifikasi yang agak sempit. Misalnya, Chatterjee \& Wernerfelt, 1991 menyarankan bahwa sumber daya fisik dan sumber daya tak berwujud, yang diyakini sangat tidak fleksibel, dapat digunakan untuk memasuki pasar yang terkait erat, sementara diversifikasi yang relatif lebih tidak terkait akan dikaitkan dengan sumber daya keuangan (Andersen \& Suat, 1998)

Secara tradisional, manajemen pemasaran menekankan pertumbuhan penjualan sebagai tujuan strategis utama berdasarkan asumsi bahwa peningkatan volume penjualan menciptakan ekonomi di banyak area yang meningkatkan profitabilitas. Dengan demikian, 
peningkatan penjualan yang berkelanjutan diasumsikan menurunkan biaya total rata-rata per unit yang akan digabungkan dengan tingkat penjualan yang lebih tinggi untuk meningkatkan kinerja laba perusahaan. Namun, dalam praktiknya, peningkatan penjualan tidak selalu dibarengi dengan keuntungan yang lebih besar meskipun penelitian menunjukkan bahwa harus ada hubungan positif antara keduanya. Hal ini telah memfokuskan kembali perhatian manajer pemasaran dan sarjana ke arah identifikasi tujuan strategis lainnya yang mungkin lebih relevan dengan tujuan jangka panjang dari "memaksimalkan kekayaan" perusahaan(Cronin, Joseph, 1998)

Ada beberapa konsep yang mewakili kebijaksanaan konvensional dari strategi pertumbuhan perusahaan. Urutan di mana perusahaan menggunakan strategi ini adalah fungsi dari (I) nilai yang diharapkan dari profitabilitas, biasanya diukur dengan pengembalian investasi, dari setiap strategi dan (2) risiko, atau varian yang diharapkan dalam profitabilitas, terkait dengan setiap strategi. Bagian sebelumnya telah menunjukkan bahwa ada alasan untuk meyakini bahwa antara produk dan layanan terdapat perbedaan hasil yang diharapkan dan varian dari strategi serupa. Pada bagian ini, pertama-tama kita akan meninjau kebijaksanaan konvensional urutan strategi pertumbuhan, kemudian memperjelas masalah perusahaan jasa dalam mengikuti urutan ini, dan akhirnya menganalisis risiko yang terkait dengan urutan alternatif yang tersedia untuk perusahaan jasa.(Carman \& Langeard, 1980)

Salah satu anugerah sumber daya penting untuk pertumbuhan usaha baru adalah kemampuan teknologi. Perusahaan dengan kekuatan teknologi lebih mudah diterima oleh pasar melalui biaya rendah (Chen et al., 2009)

Secara umum, penulis yakin langkah selanjutnya untuk meningkatkan pertumbuhan pasar dari sudut pandang maksimalisasi keuntungan dan minimalisasi risiko adalah dengan menjual paket layanan yang ada ke segmen pasar baru. Melakukan ekspansi pasar, tetapi kali ini perluasan pasar didasarkan pada segmen sosiodemografi baru daripada segmen geografis baru. Biasanya jenis ini melakukan perluasan pasar

\section{Faktor Budaya}

Budaya, subkultur, dan kelas sosial memberikan pengaruh yang sangat penting dalam perilaku pembelian konsumen. Budaya adalah penentu mendasar dari keinginan dan perilaku seseorang. Melalui keluarga dan institusi penting lainnya, seorang anak yang tumbuh di Amerika Serikat dihadapkan pada nilai-nilai seperti pencapaian dan keberhasilan, aktivitas, efisiensi dan kepraktisan, kemajuan, kenyamanan, individualisme, kebebasan, kenyamanan eksternal, kemanusiaan, dan kemudaan(Kotler \& Keller, n.d.). Seorang anak yang tumbuh di negara lain mungkin memiliki pandangan yang berbeda tentang diri, hubungan dengan orang lain, dan ritual. Seorang marketing harus memperhatikan dengan cermat nilai-nilai budaya di setiap negara untuk memahami cara terbaik memasarkan produk yang ada dan menemukan peluang untuk produk baru. Komunikasi pada pasar internasional adalah komunikasi yang melintasi batas negara untuk tujuan bisnis. Komunikasi di antara orang-orang dari budaya 
yang sama seringkali cukup sulit. Oleh karena itu, komunikasi antara orang-orang dari budaya yang berbeda dari sudut pandang bahasa, nilai, pelanggan, dan cara berpikir, akan jauh lebih sulit, dengan tingkat miskomunikasi yang hampir tak terhindarkan (Ferraro, 2006). Masalah dalam komunikasi pemasaran yang dilakukan secara lintas budaya seringkali muncul ketika peserta dari satu budaya tidak dapat memahami perbedaan yang ditentukan secara budaya dalam praktik komunikasi, tradisi, dan budaya dan pemrosesan pemikiran dalam konteks budaya lain. Literatur komunikasi pemasaran yang difokuskan pada periklanan mendukung hipotesis bahwa konten iklan berbeda antar negara(Kotler \& Keller, n.d.).

Budaya organisasi juga diartikan sebagai pengetahuan sosial dalam suatu organisasi yang meliputi aturan, norma, dan nilai-nilai yang membentuk sikap dan perilaku karyawan, maka definisi yang disampaikan oleh J. Chatman dan DL Caldwell dalam Colquitt, dkk, sebagai berikut: "Budaya organisasi sebagai pengetahuan sosial bersama dalam suatu organisasi mengenai aturan, norma, dan nilai yang membentuk sikap dan perilaku karyawannya (Colquitt, et al, 2009: 546).

Penelitian periklanan internasional telah mengkonfirmasi perbedaan konten iklan antar negara. Premis yang mendasari penelitian ini menunjukkan bahwa iklan, sebagian, mencerminkan sistem sosial masing-masing negara (Emery dan Tian, 2003; McLeod dan Kunita, 1994; Mueller, 1992; Ramaprasad dan Hasegawa, 1992; Zandpour, Chang, dan Catalano, 1992).

Nilai, norma, dan karakteristik yang tertanam dalam pesan iklan muncul dalam berbagai budaya bisa ke tingkat yang lebih besar atau lebih kecil (Emery dan Tian, 2003; Mueller, 1993). Oleh karena itu pemahaman tentang pentingnya nilai budaya dalam periklanan memiliki nilai praktis yang besar dalam komunikasi pemasaran. Menentukan perbedaan nilai budaya harus memandu perumusan strategi komunikasi pemasaran internasional (Munson dan McIntyre, 1979). Mengabaikan makna budaya yang tertanam dalam periklanan dapat menyebabkan salah tafsir dari pesan yang dimaksudkan perusahaan (McCracken, 1987). Miskomunikasi semacam itu terutama bertanggung jawab atas kegagalan bisnis di pasar internasional.

Untuk mencocokkan pemasaran dengan preferensi konsumen, perilaku pembelian, dan pola penggunaan produk, pemasar mendapat manfaat dari pemahaman lingkungan budaya pasar. Perusahaan bisnis tidak boleh berfokus pada perbedaan budaya hanya untuk menyesuaikan program komunikasi pemasaran agar dapat diterima oleh konsumen. Ini untuk menyarankan bahwa perusahaan juga harus mengidentifikasi kesamaan budaya, untuk mengidentifikasi peluang dan memodifikasi pemasaran standar

strategi berdasarkan teori komunikasi pemasaran diinformasikan dengan informasi budaya. Bekerja secara terampil dengan persamaan dan perbedaan budaya ini di pasar dunia merupakan tugas pemasaran yang penting untuk bisnis. 
Bisnis internasional sering dilakukan melalui berbagai cara dari budaya ke budaya, komunikasi pemasaran dapat ditingkatkan ketika para manajer dilatih secara lintas budaya untuk menyadari area yang kemungkinan menciptakan hambatan komunikasi dan konflik. Bisnis internasional secara umum ditingkatkan ketika orang-orang dari budaya yang berbeda menemukan pendekatan baru untuk memecahkan masalah dengan menciptakan solusi yang menggabungkan perspektif budaya dan memeriksa masalah yang dihadapi dari sudut pandang yang berbeda satu sama lain.

\section{Faktor Sosial}

Selain faktor budaya, faktor sosial seperti kelompok referensi, keluarga, dan peran serta status sosial mempengaruhi perilaku pembelian kita. Keluarga adalah kelompok konsumen terpenting dalam masyarakat, dan anggota keluarga merupakan kelompok referensi utama yang paling berpengaruh. Ada dua keluarga dalam kehidupan pembeli. Keluarga orientasi terdiri dari orang tua dan saudara kandung. Melalui orang tua seseorang memperoleh orientasi terhadap agama, politik, dan ekonomi dan rasa ambisi pribadi, harga diri, dan cinta.8 Bahkan jika pembeli tidak lagi banyak berinteraksi dengan orang tuanya, pengaruh orang tua terhadap perilaku dapat menjadi penting. Hampir 40 persen keluarga memiliki asuransi mobil dengan perusahaan yang sama dengan orang tua (Kotler \& Keller, n.d.)

Teori sementara terkait adopsi teknologi berguna untuk menjelaskan hasil adopsi teknologi, teori perilaku berfokus pada tingkat analisis individu di mana perilaku manusia memiliki dampaknya. The Theory of Reasoned Action (TRA) menurut Ajzen (1991) menyatakan bahwa sikap dan norma subjektif mempengaruhi niat berperilaku. Davis (1989) menerapkan TRA ke tingkat individu dari perilaku adopsi teknologi. Hasil yang dihasilkan adalah salah satu teori perilaku adopsi teknologi yang paling dikenal, Technology Acceptance Model (TAM). Dua konstruksi utama yang mempengaruhi niat individu untuk menggunakan teknologi adalah Perceived Usefulness (PU) dan Perceived Ease of Use (PEU).

Dalam kasus UKM di mana proses pengambilan keputusan bisnis untuk pemilik atau manajer bisnis identik dengan proses pengambilan keputusan individu. Dari literatur, perilaku adopsi teknologi baru yang ditunjukkan oleh bisnis mungkin menggambarkan perilaku yang sama oleh satu individu. Hal ini dapat disimpulkan sebagai sikap dan perilaku adopsi teknologi tingkat bisnis yang digeneralisasi mungkin juga dapat dijelaskan secara efektif oleh TAM

Penelitian yang berfokus pada factor social relative sedikit, penelitian ilmiah tentang faktor sosial dan peran komunikasi pemasarannya dalam industri bisnis dan organisasi berkembang. Pemasaran di bidang ini mengacu pada penggunaan teknologi media sosial untuk melakukan aktivitas pemasaran perusahaan. Bahkan banyak UKM menghadapi banyak keterbatasan termasuk adopsi teknologi sebagai kendala bagi kelompok ini untuk meraih peluang yang dapat membantu perusahaan meningkatkan kinerja bisnisnya, pemasaran media sosial 
dipersepsikan sebagai saluran komunikasi bisnis yang sangat menjanjikan. Namun, dengan sumber daya yang terbatas, kesalahpahaman dan kurangnya pemahaman tentang teknologi akan berdampak parah pada bisnis kecil.

\section{Faktor Personal}

Marketing Management edition 14th: Karakteristik pribadi yang mempengaruhi keputusan pembeli meliputi usia dan tahapan dalam siklus hidup, pekerjaan dan keadaan ekonomi, kepribadian dan konsep diri, serta gaya hidup dan nilai. Karena banyak di antaranya berdampak langsung pada perilaku konsumen, penting bagi seorang marketing untuk mengikutinya dengan cermat(Kotler \& Keller, n.d.)

Kepuasan Pelanggan dan Kontras Kepuasan Pelanggan Ini Menurut Oliver [9] adalah bahwa kunci untuk mempertahankan pelanggan adalah kepuasan pelanggan, dimana dimensi kepuasan pelanggan adalah: 1) Harapan, pelanggan puas hanya jika pada kenyataannya produk yang telah mereka beli adalah sesuai atau Di luar ekspektasi / ekspektasi mereka. Produk yang baik adalah produk yang mampu memenuhi harapan / harapan pelanggannya, sehingga pelanggan akan mendapatkan pengalaman yang positif setelah membeli produk tersebut; 2) Disconfirmation subyektif, customer merasa puas jika tidak ada hal atau alasan yang berhubungan dengan ketidaksesuaian produk subjektif; 3) Performance Outcome, pelanggan merasa puas dengan keseluruhan performa produk yang dibelinya dan mendapatkan manfaat yang optimal sesuai dengan yang diinginkannya.(Setyadi \& Ali, 2017) Penelitian mengenai factor personal atau orang sudah pernah dilakukan pada penelitian sebelumnya termasuk: (Djoko Setyo Widodo, P. Eddy Sanusi Silitonga, 2017), (Agussalim et al., 2016), (Novansa \& Ali, 1926), (Elmi et al., 2016), (Novansa, Hafizh, Ali, 2017), (Limakrisna et al., 2016), (Octavia et al., 2020), and (Anggita \& Ali, 2017)

Perilaku konsumen terbagi menjadi dua, yaitu persepsi sebagai bentuk penafsiran objek dan preferensi sebagai kecenderungan pilihan pada suatu hal. Dalam melakukan pemilihan, terdapat hal-hal yang menjadi pertimbangan. (Asribestari \& Setyono, 2013)

Menurut Salvatore (2006), preferensi konsumen diungkapkan atas beberapa asumsi yang digunakan sebagai dasaran dalam preferensi konsumen adalah sebagai berikut:

1. Cita rasa seorang individu tidak berubah selama periode tertentu.

2. Adanya konsistensi, yaitu apabila konsumen yang diamati lebih menyukai objek A daripada objek B maka konsumen ini tidak akan pernah menyukai objek B daripada objek A.

3. Adanya transitivitas, yaitu jika A lebih disukai daripada B dan B lebih disukai daripada $\mathrm{C}$, maka A lebih disukai daripada $\mathrm{C}$.

4. Konsumen dapat didorong untuk membeli kombinasi barang yang manapun jika harganya dibuat cukup menarik.

Faktor personal dari konsumen pernah dilakukan pada penelitian - penelitian sebelumnya untuk memprediksi konservasi energi, daur ulang, dan pembelian serta penggunaan produk 
dengan kesadaran ekologis. Kassarjian (1971) mempelajari reaksi konsumen terhadap bensin yang mengurangi polusi udara dan menemukan bahwa ada korelasi positif antara perhatian terhadap polusi udara dan kesediaan untuk membayar harga yang lebih tinggi untuk itu. Sikap terhadap pencemaran udara (diungkapkan dengan perhatian) merupakan variabel terpenting dalam menentukan perilaku konsumen terhadap produk. Kinnear dan Taylor (1973) menyelidiki dimensi sikap dan perilaku perhatian ekologis dan menemukan mereka memiliki efek yang ditandai pada persepsi merek untuk produk binatu. Dalam sebuah penelitian yang dilakukan di Jerman Barat, Balderjahn (1988) menemukan bahwa sikap positif terhadap kehidupan yang sadar ekologis menghasilkan pembelian dan penggunaan produk yang bertanggung jawab secara ekologis, termasuk penggunaan mobil. Ini juga mendorong konsumen untuk menunjukkan kepedulian lingkungan secara umum, hal ini mendukung bermunculannya kelompok-kelompok yang mengeluarkan berbagai petisi yang relevan secara ekologis dan mendukung atau bergabung dengan organisasi yang peduli terhadap lingkungan

\section{METODE PENELITIAN}

Metode penulisan artikel ilmiah ini menggunakan studi literatur dan studi kepustakaan. Dengan mengkaji berbagai referensi sesuai dengan teori yang dibahas, khusunya dalam lingkup Manajemen Pemasaran. Disamping itu menganalisis artikel-artikel ilmiah yang bereputasi dan juga artikel ilmiah dari jurnal yang belum bereputasi. Semua artikel ilmiah yang di citasi bersumber dari Mendeley dan Scholar Google.

\section{HASIL DAN PEMBAHASAN}

\section{Pengaruh / hubungan faktor budaya terhadap kompetisi pasar}

Budaya adalah penentu mendasar dari keinginan dan perilaku seseorang (Kotler, 2012). Dalam konteks liberalisasi perdagangan, perusahaan domestik memiliki keunggulan komparatif dibandingkan perusahaan asing dalam hubungannya dengan pemangku kepentingan lokal, sementara mungkin sulit bagi mereka untuk bersaing secara biaya. Oleh karena itu, perusahaan domestik dapat menanggapi meningkatnya persaingan luar negeri dengan memperkuat hubungan mereka dengan konsumen lokal, karyawan, dan pemangku kepentingan lainnya. Dalam artian, dengan meningkatkan inisiatif sosial dan lingkungan, perusahaan dapat membedakan diri dan membangun penghalang perdagangan "lunak" yang merugikan pesaing asing mereka(Flammer, 2014).

Budaya organisasi dan efektivitas organisasi memiliki hubungan yang sangat erat. Sehingga keduanya tidak dapat dipisahkan dari kehidupan organisasi dalam rangka mencapai tujuannya. Setiap anggota organisasi dapat saja berasal dari berbagai suku bangsa dengan latar belakang adat istiadat yang berbeda, tapi semuanya memiliki budaya organisasi yang membedakan organisasinya dengan organisasi lainnya(Tjiharjadi, 2007) 
Faktor budaya telah lama diketahui mempengaruhi komunikasi dan potensi keberhasilan persaingan dalam menjalankan bisnis internasional. Kesadaran budaya membentuk bagaimana perusahaan bisnis berperilaku di pasar internasional yang direfleksikan secara lintas budaya. Diakui secara luas bahwa faktor budaya bertindak sebagai penghalang tak terlihat dalam komunikasi pemasaran internasional. Memahami perbedaan budaya adalah salah satu keterampilan paling signifikan bagi perusahaan untuk dikembangkan agar memiliki keunggulan kompetitif dalam bisnis internasional(Tian \& Borges, 2011)

Negosiasi bisnis, jenis format penting lain untuk komunikasi pemasaran, juga membutuhkan kesadaran akan perbedaan budaya. Sebuah studi baru-baru ini oleh Chang (2003) menyimpulkan bahwa dalam masyarakat Cina, orang-orang menekankan "permainan zerosum" di sebagian besar aktivitas persaingan bisnis mereka(Tian \& Borges, 2011)

\section{Pengaruh / hubungan faktor sosial terhadap kompetisi pasar}

Keluarga adalah kelompok konsumen terpenting dalam masyarakat, dan anggota keluarga merupakan kelompok referensi utama yang paling berpengaruh (Kotler, 2012). Tingkat kebutuhan masyarakat di dalam suatu daerah tertentu akan berbeda dengan daerah lainnya. Dalam konteks ini, perusahaan domestik memiliki keunggulan komparatif dibandingkan perusahaan asing dalam hubungannya dengan pemangku kepentingan lokal, sementara mungkin sulit bagi mereka untuk bersaing secara biaya. Perusahaan domestic atau perusahaan dengan pengetahuan domestic akan lebih mudah mengikuti kompetisi pasar (Flammer, 2014).

Hadirnya layanan jasa dari perusahaan finance diyakini masyarakat luas sebagai lembaga pemberi layanan untuk mempermudah melakukan pembelian barang yang diinginkan, sehingga kebutuhan yang biasanya tidak mudah didapatkan dengan pembayaran tunai bisa terbantu dengan hadirnya perusahaan pembiayaan yang menerapkan sistem kredit, yang dapat dicicil dalam jangka waktu yang fleksibel dengan bunga yang terjangkau. Dalam hal ini perusahaan finance harus mengelola usahanya dengan manajemen yang baik, hal ini dilakukan untuk menghadapi persaingan yang semakin ketat dari pendatang baru maupun perusahaan sejenis yang bergerak di bidang pembiayaan (finance), sehingga perusahaan dapat bertahan hidup dan terus berkembang dimasa yang akan datang. Kelangsungan hidup perusahaan di era kompetisi global menuntut manajemen untuk menyusun perencanaan strategis dalam menghadapi perubahan-perubahan yang akan terjadi. Perubahan-perubahan yang perlu di respon oleh perusahaan bukan hanya berorientasi pada produk perusahaan saja, melainkan pada aspek-aspek penting yang menyangkut kinerja suatu perusahaan sebagai entitas masyarakat(Yeni et al., 2019).

Manfaat sosial dan kepercayaan mempengaruhi minat beli online (Liu \& Guo, 2017). Pudaruth \& Nursing, (2017) menemukan kemudahan mempengaruhi niat beli. Penelitian yang dikembangkan oleh (Silva et al., 2019) bahwa kepercayaan memiliki kemampuan dalam memediasi risiko yang dirasakan terhadap minat beli online, kemudian dari perspektif 
yang berbeda kepercayaan juga mampu memediasi e-wom terhadap minat beli online (Bhandari \& Rodgers, 2018). Penelitian (Silva et al., 2019) sebelumnya menjadikan variabel kepercayaan sebagai mediasi antara persepsi risiko dan ewom terhadap minat beli online, dan dari perspektif yang berbeda (Bhandari \& Rodgers, 2018) menemukan bahwa variabel kepercayaan mampu memediasi antara e-wom terhadap minat beli online(Ilhamalimy, 2020)

\section{Pengaruh / hubungan faktor personal terhadap kompetisi pasar}

Penelitian pada artikel "Attitude toward Using m-Commerce: The Analysis of Perceived Usefulness, Perceived Ease of Use, and Perceived Trust: Case Study in Ikens Wholesale Trade, Jakarta - Indonesia" menghasilkan salah satu output bahwa dilihat dari target pengurus Grup Ikens, keputusan perpindahan saluran penjualan dari offline ke online sangat tepat. Selain sebagian besar pelanggan berada di luar kota (Jakarta), persaingan juga semakin marak. Kuesioner menunjukkan bahwa 60\% pelanggan sudah memiliki aplikasi seluler serupa. Ini menandakan bahwa Ikens bukanlah yang pertama. Pelanggan Ikens adalah pemilik toko yang kebanyakan mengelola tokonya sendiri dan oleh karena itu keputusan berbelanja juga dibuat langsung oleh pemiliknya(Indarsin \& Ali, 2020)

Membangun perusahaan berkualitas tinggi yang merupakan karakteristik perusahaan yang berorientasi pasar. Penerapannya melalui suatu proses dan menuntut kerjasama dari berbagai pihak yang ada dalam organisasi. Berdasarkan hasil penelitian sebelumnya, semakin tinggi orientasi pasar suatu organisasi, maka semakin tinggi pula kinerja yang mampu dicapai (Ali et al., 2005; Matanda dan Ndubisi, 2009; Felgueira dan Ricardo, 2012; Asgar et al.., 2013). Hafeez dkk. (2011) yang mendeklarasikan orientasi pasar dan orientasi wirausaha dapat meningkatkan kinerja usaha bagi UKM. Namun tidak di Indonesia, berdasarkan pantauan orientasi pasar banyak penelitian yang menitikberatkan pada lingkungan strategis di negara maju, sangat sedikit yang melakukan penelitian di negara berkembang khususnya pada UKM (Teck, 2012). Hasil penelitian pada UKM menunjukkan bahwa tidak ada pengaruh antara orientasi pasar terhadap kinerja usaha $(\mathrm{P}=0,078)$. Hasil ini kontras dengan hasil penelitian sebelumnya yang mengatakan bahwa terdapat pengaruh yang signifikan terhadap kinerja bisnis. Perbedaan hasil tidak hanya karena perbedaan objek penelitian. Memang sebagian besar penelitian yang menemukan ada pengaruh yang signifikan orientasi kinerja pasarbisnis dilakukan pada industri besar. Industri jenis ini telah mengadopsi konsep orientasi pasar, seperti orientasi pasar dan orientasi pesaing serta fungsi koordinasi, sedangkan untuk strategi usaha kecil belum fokus kepada pelanggan dan pesaing. 32-47\% menyatakan bahwa pelaku usaha untuk membentuk orientasi pasar terdapat tiga faktor utama yaitu orientasi kepada pelanggan, pesaing dan fungsi koordinasi. Sebanyak 59\% pemilik usaha dan pendiri menyatakan bahwa orientasi pasar penting untuk meningkatkan kinerja bisnis. Namun hasil ini memberikan fakta bahwa sebagian besar UKM tidak memiliki budaya berorientasi pasar. Hal ini didukung oleh observasi bahwa UKM kurang memiliki motivasi untuk memenangkan persaingan(Octavia \& Ali, 2017) 
Dalam belanja tentu konsumen tidak serta merta akan berubah dan meninggalkan tempat belanja lama (red. retail offline) sebagai tempat belanja produk fashion mereka namun hadirnya tempat belanja baru (red. retail online) pun yang sekarang terbukti dalam penelitian ini belum bisa merubah perilaku konsumen dan berbelanja produk fashion. Tempat belanja lama tetap menjadi pilihan belanja khususnya untuk dua generasi (yaitu gen $\mathrm{X}$ dan gen $\mathrm{Y}$ ) yang ada saat ini yang bisa dikatakan memiliki usia di atas $>22$ tahun. Tentu saja ada bisa yang terjadi ketika dikatakan usia yang paling labil adalah generasi Y 22 thn -41 thn yang mana generasi ini adalah generasi yang sebagian bisa melakukan belanja online dan sebagian lagi tetap belanja di retail offline. Data berbeda ditunjukan bagi generasi X yang rentang usia mereka >42 tahun yang menurut data merupakan generasi yang setia pada retail offline sebagai tempat belanja mereka karena selama masa hampir setengah hidup mereka menggunakan metode belanja di retail offline. Oleh karena itu jika dikatakan bahwa retail offline tetap menjadi primadona bagi generasi ini yang merupakan generasi yang loyal terhadap retail offline dan merupakan konsumen utama pada retail offline(Suleman et al., 2020).

Munculnya pasar modern menyebabkan penurunan jumlah konsumen pada pasar tradisional karena adanya pasar modern diikuti dengan adanya perubahan preferensi masyarakat dalam memilih tempat belanja antara Pasar Tradisional Karangayu dan Pasar Modern Giant Superdome. Hal ini sesuai dengan pandangan Kotller bahwa jika di sekitar lokasi pasar tradisional terdapat tempat-tempat yang menawarkan barang yang sama dengan barang yang ditawarkan di pasar tradisional dapat menimbulkan persaingan, mencakup semua tawaran dan barang pengganti yang bersaing secara aktual dan potensial, yang bisa dipertimbangkan oleh pembeli(Asribestari \& Setyono, 2013).

\section{Pengaruh / hubungan factor budaya terhadap pertumbuhan pasar}

Profil budaya berdasarkan survei yang dilakukan oleh Denison menemukan empat dimensi budaya: pertama, misi terdiri dari arah strategis, tujuan, dan visi. Organisasi yang sukses memiliki tujuan yang jelas, yang menentukan arah tujuan organisasi dan sasaran strategis dan mengungkapkan visi tentang bagaimana organisasi akan terlihat; kedua, konsistensi terdiri dari nilai primer, persetujuan, koordinasi dan integrasi (Mukhtar et al., 2016).

Dari sisi tantangan bisnis, pada era globalisasi seperti sekarang ini pertumbuhan bisnis menjadi sangat pesat sekaligus menimbulkan persaingan yang sangat kompetitif, baik di pasar dalam negeri maupun di pasar luar negeri. Jumlah penduduk Indonesia kurang lebih 250 juta jiwa dengan laju pertumbuhan penduduk yang cukup signifikan merupakan tantangan bagi para agen prudential untuk mengembangkan bisnis prudential di Indonesia. Kemudian dengan minimnya pengetahuan masyarakat Indonesia tentang pentingnya ber asuransi akan menjadi tantangan tersendiri bagi para agen atau tenaga pemasaran prudential. Hal ini membuat prudential mengembangkan pu sat pelatihan dan pengembangan tenaga pemasaran baik dari jalur distribusi keagenan mau pun partnership distribution yang dikenal dengan nama Pru Sales Academy (Hafidz, 2018). 
Pasar asuransi jiwa di dalam negeri pun berkembang pesat dan sekarang ini sudah banyak sekali perusahaan asuransi jiwa di dalam negeri baik dari pendatang baru maupun pesaing yang sudah ada sebelumnya. Banyaknya merek-me- rek baru atau kompetitor asuransi jiwa penda- tang baru membuat konsumen semakin banyak pilihan dan setiap asuransi jiwa pastinya ma- sing-masing memiliki keunggulan untuk ber- saing dan menawarkan produk produk yang bervariasi kepada konsumen. Selain itu, per- saingan yang ketat antar merek menjadikan konsumen memilki posisi yang semakin kuat dalam posisi tawar-menawar. Dapat dilihat pada Gambar 1.1 berikut pertumbuhan perusahaan asuransi jiwa dari tahun 2011 sampai dengan 2015(Hafidz, 2018).

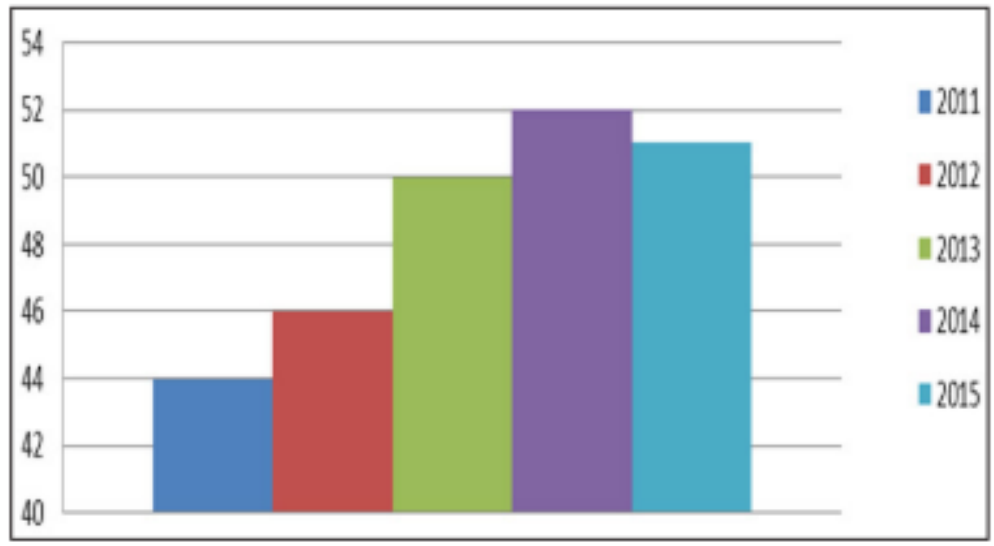

\section{GAMBAR 1.1 PERTUMBUHAN PERUSAHAAN ASURANSI JIWA DI INDONESIA}

Budaya organisasi memiliki hubungan yang kuat dengan efektivitas organisasi. Keduanya dapat memberikan dampak yang besar bagi masa depan dan pertumbuhan organisasi. Berbagai aspek budaya telah ditemukan di perusahaan multinasional yang beroperasi di Indonesia. Semuanya memiliki situasi budaya yang sama dan harus menghadapinya untuk mencapai kemajuan yang baik demi efektivitas perusahaan agar dapat terus tumbuh dan bisa memenangkan persaingan(Tjiharjadi, 2007).

Budaya organisasi yang kuat dan mengakar pada diri setiap individu seperti itulah yang membuat orang Jepang berhasil mengubah citra produk buatannya dari low class quality menjadi high class quality sehingga mampu menembus pasaran dunia. Semua ini dapat tercipta karena orang Jepang memiliki prinsip hidup yang mengakari kemampuannya dalam berorganisasi. Takeo Fujisawa, salah seorang pendiri Honda Motor Company, pernah mengatakan bahwa sebenarnya, 95\% manajemen Jepang dan Amerika tidak berbeda. Hanya $5 \%$ yang berbeda itu terletak pada aspek-aspek yang sangat penting. Orang Jepang juga belajar ilmu manajemen dari orang Amerika. Tetapi ilmu itu telah dikombinasikan dengan 
budaya Jepang yang akhirnya menghasilkan satu manajemen khas Jepang yang terkenal keampuhannya, yaitu Kaizen(Tjiharjadi, 2007).

\section{Pengaruh / hubungan faktor sosial terhadap pertumbuhan pasar}

MenurutRangkuti (2014), penelitian menunjukkan bahwa kinerja perusahaan dapat ditentukan oleh kombinasi faktor internal dan eksternal. Kedua faktor tersebut harus dipertimbangkan dalam analisis SWOT. Analisis SWOT adalah singkatan dari lingkungan internal strengths dan weaknesses serta lingkungan eksternal opportunities dan threats yang dihadap di dunia bisnis. Analisis SWOT dibandingkan antara faktor eksternal peluang (opportunities) dan ancaman (threats) dengan faktor internal keluatan (strengths), dan kelemahan weaknesses.(Yeni et al., 2019)

Saat ini bisnis retail di Indonesia berkembang pesat sehingga menimbulkan persaingan terutama sejak masuknya investor asing dalam bisnis ini. Persaingan yang tinggi di sektor ritel memaksa peritel untuk terus berinovasi guna memenangkan pelanggan untuk memenangkan persaingan. Untuk itu dalam mengembangkan pemasarannya perusahaan harus berorientasi pada konsumen, sehingga perusahaan dapat mengidentifikasi dan mengetahui apa yang dibutuhkan konsumen(Setyadi \& Ali, 2017).

Reputasi dari merek adalah rangkaian asosiasi (persepsi) yang ada di benak konsumen, sebuah merek biasanya disusun menjadi suatu makna. Relasi dengan sebuah brand akan semakin kuat jika dilandasi oleh pengalaman dan mendapatkan banyak informasi. Citra atau asosiasi merepresentasikan persepsi yang mencerminkan realitas objektif atau tidak. Citra yang terbentuk dari asosiasi (persepsi) inilah yang mendasari keputusan membeli bahkan loyalitas merek (brand loyalty) dari konsumen(Setyadi \& Ali, 2017).

Manusia, seperti yang kita tahu, adalah mahluk sosial. Konsumen sebagai manusia membutuhkan hubungan sosial dan memiliki interaksi dan hubungan sosial dengan orang lain. Nitzan dan Libai (2011) mengemukakan bahwa definisi sosial dengan kata lain sebagai koneksi dan transmisi informasi adalah fakta dan praktik umum manusia dan / atau pelanggan. Lebih jauh, pengaruh sosial dapat terjadi bila ada transmisi informasi antar manusia yang terhubung satu sama lain. Dengan demikian, seseorang mungkin memiliki perilaku membeli yang menyimpang dari praktiknya sendiri ketika ada transmisi informasi dari orang-orang yang terhubung dengannya. Misalnya, seseorang mungkin menerima pengalaman penggunaan produk dari teman / kerabat / anggota keluarganya. Misalkan orang-orang yang terhubung memiliki pengalaman buruk dengan produk, mungkin ada dampak pada pelanggan yang membuat keputusan untuk berbelanja produk. Selain itu, Bell, Corsten dan Knox (2011) juga menunjukkan bahwa perilaku pembelian yang tidak terencana dapat dipengaruhi oleh faktor out-of-store (red. tidak tersedianya produk pada toko) khususnya dari mulut ke mulut dari keluarga dan teman. Demikian pula, Chang, Molly, dan Yan (2011) menemukan pengaruh karakteristik sosial terhadap respon emosional positif pelanggan. Namun, temuan penelitian Inman, Winer dan Ferraro (2009) terhadap proposisi 
efek sosial pada pengambilan keputusan pelanggan. Dengan demikian, pengetahuan dan teori penelitian saat ini masih jarang. Secara khusus, masih ada pertanyaan apa hasil dari efek sosial, ketika pengaruh orang yang terhubung dengan pelanggan terjadi dalam situasi di dalam toko. Sekali lagi, hingga saat ini, hanya ada sedikit studi yang menyelidiki masalah khusus ini. Secara khusus, sehubungan dengan studi apriori (misalnya Bell, Corsten \& Knox, 2011; Chang, Molly \& Yan, 2011; Nitzan \& Libai, 2011), dapat disimpulkan bahwa mungkin ada dampak efek sosial pada pelanggan. perilaku pembelian di dalam toko yang tidak direncanakan(Chomvilailuk \& Butcher, 2014).

\section{Pengaruh / hubungan faktor personal terhadap pertumbuhan pasar}

Untuk mengukur keterlibatan pelanggan, pengukuran harus dilakukan dalam konteks strategi pemasaran perusahaan dan pelanggan itu sendiri, di mana perilaku yang diperlihatkan akan tercipta dan terhubung dengan pelanggan. Kunci terpenting untuk mempertahankan keuntungan masa depan yang stabil tidak begitu jelas hanya dengan menjaga hubungan baik dengan pelanggan - tetapi kita harus memperdalam hubungan kita dan lebih terhubung dengan mereka (Shefrin, 2007), kita dapat mengatakan bahwa hubungan emosional yang mapan antara pelanggan dan perusahaan akan sangat memengaruhi kinerja bisnis dan atau keuangan, termasuk retensi pelanggan, penjualan silang, pembagian dompet, frekuensi pembelian, profitabilitas pendapatan, dan pertumbuhan hubungan. Penelitian menunjukkan bahwa pelanggan yang terlibat penuh $23 \%$ jauh lebih baik daripada pelanggan rata-rata dalam hal pangsa dompet, profitabilitas pendapatan, dan pertumbuhan hubungan.(Mansur \& Buana, 2019).

Meningkatkan kapabilitas manajemen wirausaha melalui pelatihan kewirausahaan (Putha, 2014). Pelatihan kewirausahaan memiliki kemampuan dan keahlian di bidang manajemen dibandingkan dengan wirausaha yang tidak mengikuti pelatihan. Hal ini sejalan dengan pendapat Alasadi dan Al Sabbagh (2015) bahwa dengan adanya pelatihan di bidang manajemen maka pengusaha akan lebih mampu meningkatkan kinerja usahanya. Pelatihan adalah perencanaan dan tindakan sistematis untuk meningkatkan keterampilan dan kemampuan melalui pembelajaran untuk meningkatkan kinerja. Program pelatihan tradisional sebagian besar berfokus pada peningkatan jiwa kewirausahaan tetapi hanya sedikit yang mencoba menyentuh kegiatan manajemen sebagai bagian dari program pelatihan. Ciri-ciri kepribadian yang ditunjukkan sebagai keahliannya merupakan salah satu faktor dalam meningkatkan kinerja bisnis (Krueger, 1998). Keterampilan manajemen adalah kemampuan jaringan untuk mengembangkan kewirausahaan, berinisiatif, mengambil keputusan, memanfaatkan peluang, inovatif, mampu memecahkan masalah dan berpikir strategis. Eikebrokk dan Olson (2009) menyatakan ada hubungan positif antara pelatihan, kompetensi dan kinerja bisnis. Altinay dan Chaterine (2011) menyatakan pendidikan dan pelatihan sangat dibutuhkan terutama untuk mengetahui apa yang diinginkan dan dibutuhkan oleh konsumen. Gheorghe (2013) menyatakan orientasi kewirausahaan dan pembelajaran dasar di bidang pemasaran (pelatihan) akan mempengaruhi kemampuan perusahaan dalam berinovasi. Bahkan lingkungan adalah variabel antara orientasi dan kinerja kewirausahaan 
(Milavanovic dan Zoran, 2014). Untuk meningkatkan kinerja keterampilan manajemen usaha yang dibutuhkan dapat diperoleh melalui pelatihan kewirausahaan (Gambar 1 ).(Octavia \& Ali, 2017)

Hampir $35 \%$ atau sekitar 88,1 juta dari 250 juta penduduk Indonesia terdaftar sebagai pengguna internet [1]. Angka ini secara langsung mendorong pesatnya pertumbuhan dan transaksi perdagangan online yang biasa dikenal dengan e-commerce dan juga penjualan online. Saluran penjualan online juga mencatat angka yang memuaskan. McKinsey (2016) melalui penelitiannya melaporkan bahwa pada tahun 2015, 34\% penduduk Indonesia melakukan transaksi melalui saluran e-commerce atau penjualan online dan dalam laporannya diperkirakan pada tahun 2020 angka ini akan meningkat pesat hingga 53\% dari populasi di Indonesia [2] (Indarsin \& Ali, 2020)

Secara demografis, sebagian besar pelanggan Ikens yang berada di rentang usia 41 hingga 50 tahun berada pada usia produktif di mana rentang usia tersebut paling banyak mengalami perubahan dan perkembangan teknologi dari analog ke digital. Mereka adalah kelompok yang cepat beradaptasi dan mampu menggunakan perangkat smartphone dengan baik. Selain itu, hampir seluruh responden merupakan pemilik toko atau pelaku usaha yang berani mencoba hal-hal baru guna memajukan usahanya sehingga jalur yang ditempuh manajemen Ikens Group tidak menjadi masalah besar dan tidak menjadi kendala bagi mereka(Indarsin \& Ali, 2020).

Aksesibilitas merupakan hal yang cukup mempengaruhi persepsi dan preferensi konsumen terhadap Pasar Karangayu dan Giant Superdome. Aksesibilitas dilihat dari jarak antara rumah dengan pasar, pemilihan moda transportasi dan biaya transportasi. Diketahui bahwa adanya limitasi berupa pulau jalan dapat mengurangi kemudahan aksesibilitas, terutama bagi konsumen yang berada di seberang pasar. Hal ini dikarenakan mereka harus memilih jalan berputar dan menumouh jarak yang lebih jauh saat menuju pasar (Asribestari \& Setyono, 2013).

\section{Pengaruh / hubungan kompetisi pasar terhadap pertumbuhan pasar}

Pendapatan Premi Prudential Neto setiap tahunya memang selalu mengalami kenaikan namun jika diperhatikan pada angka pertumbuhannya tidak pernah bisa mencapai pada pencapaian pada tahun 2011 bahkan sejak tahun 2011 setiap tahunya selalu mengalami penurunan untuk pertumbuhan preminya dapat di ambil kesimpulan terdapat masalah dalam keputusan pembelian pada PT. Prudential Life Assurance. Prudential Indonesia adalah "pemimpin" pasar dalam penjualan produk asuransi jiwa yang dikaitkan dengan investasi (unit link) pertamanya di tahun 1999”. Sebagai market leader perusahaan asuransi jiwa, "Prudential Indonesia selalu berusaha untuk menyediakan produk unit link yang dirancang untuk memenuhi dan melengkapi kebutuhan nasabahnya, dalam setiap tahap kehidupan, mulai dari usia kerja, pernikahan, kelahiran anak, pendidikan anak, dan masa pensiun”. Dalam industri asuransi jiwa iklim kompetisi terbilang tinggi hal ter- sebut juga yang 
dihadapi oleh Prudential khususnya dalam bisnis jasa asuransi unit link, namun manajemen menanggapi hal tersebut sebagai sebuah tantangan. Setiap perusahaan harus dapat melakukan usahanya dengan lebih efisien, efektif dan produktif. Tingkat kompetisi yang tinggi ini memacu tiap-tiap perusahaan untuk mempertahankan kelangsungan hidup organisasinya termasuk perusahaan Prudential(Hafidz, 2018)

Konosuke percaya bahwa pertumbuhan perusahaan merupakan "pengakuan" masyarakat terhadap nilai dari aktifitas yang dijalankan perusahaan. Selain itu Konosuke juga menanamkan prinsip bahwa bila perusahaannya tidak dapat menjamin pelayanan purna jual dari produk yang dijual, lebih baik perusahaannya mengurangi skala bisnis atau jenis produk yang dijual. Produk, penjualan, dan pelayanan adalah tiga aspek yang menurutnya tak dapat dipisahkan. Sepeninggal Konosuke, perusahaan Matsushita yang memiliki brand product National tersebut, tetap memiliki ciri khas yang mengantarkan image konsumen akan high quality dari brand National miliknya(Tjiharjadi, 2007).

Saat ini bisnis retail di Indonesia berkembang pesat sehingga menimbulkan persaingan terutama sejak masuknya investor asing dalam bisnis ini. Persaingan yang tinggi di sektor ritel memaksa peritel untuk terus berinovasi guna memenangkan pelanggan untuk memenangkan persaingan. Untuk itu dalam mengembangkan pemasarannya perusahaan harus berorientasi pada konsumen, sehingga perusahaan dapat mengidentifikasi dan mengetahui apa yang dibutuhkan konsumen(Setyadi \& Ali, 2017).

Kualitas layanan: sebagai bentuk awal dan kinerja produk merupakan bagian utama dari strategi atau institusi perusahaan untuk mencapai keunggulan yang berkelanjutan, baik sebagai pemimpin pasar maupun sebagai strategi untuk terus berkembang. Keunggulan suatu produk tergantung pada keunikan atau ciri Ciri khas dan kualitas yang ditunjukkan oleh produk tersebut, apakah sesuai dengan harapan dan keinginan konsumen Kotler dan Armstrong, [11]. Kualitas pelayanan berpusat pada upaya memenuhi kebutuhan dan keinginan konsumen serta ketepatan penyampaian untuk menyeimbangkan harapan konsumen. Menurut Tjiptono [12] kualitas layanan merupakan tingkat keunggulan yang diharapkan dan pengendalian atas tingkat keunggulan untuk memenuhi keinginan konsumen. Konsumen yang mengonsumsi dan menikmati layanan perusahaan harus menentukan kualitas layanan yang diberikan. Apabila jasa yang diterima konsumen melebihi atau sama dengan harapannya, maka dapat dikatakan bahwa jasa yang diberikan oleh penyedia jasa itu baik atau memuaskan begitu pula sebaliknya(Setyadi \& Ali, 2017).

Pada perkembangannya, baik pasar tradisional maupun pasar modern, menjadi sarana penunjang perekonomian masyarakat di sektor perdagangan. Semula pasar memiliki skala pelayanan lingkungan permukiman yang kemudian berkembang hingga mencapai skala pelayanan kota dan wilayah. Perkembangan pasar di Kota Semarang cukup pesat, tidak hanya pasar tradisional, pertumbuhan pasar modern di Kota Semarang juga dapat dikatakan cukup pesat. Data tahun 2010 yang terdapat pada Masterplan Pola Perpasaran Kota 
Semarang menunjukkan jumlah pasar tradisional di Kota Semarang, baik skala lingkungan hingga skala kota, adalah 53 pasar dan jumlah pasar modern di Kota Semarang berjumlah 724 pasar yang terbagi menjadi hypermart, supermarket, minimarket dan pertokoan. Menurut Fox dan Sethuraman (2006), munculnya berbagai jenis pasar nontradisional ini dapat meningkatkan kompetisi antara pasar tradisional dengan pasar modern. Kompetisi pasar ini berupa kompetisi dalam menarik minat pengujung untuk melakukan berbelanja di pasar tersebut. Bentuk kompetisi pasar ini juga didukung dengan adanya perubahan perilaku masyarakat yang kini semakin modern mengakibatkan kecenderungan perpindahan tempat belanja dari pasar tradisional menuju pasar modern. Salah satu contoh kompetisi pasar terjadi pada Pasar Karangayu dan Giant Superdome. Kedua pasar ini terletak di lokasi yang sama yaitu di Kelurahan Karangayu, Kecamatan Semarang Barat. Kedua pasar ini memiliki karateristik yang cukup mirip yaitu menjual barang kebutuhan harian, terletak dilokasi yang sama dan memiliki jangkauan pelayanan Kota Semarang (Asribestari \& Setyono, 2013).

\section{Kerangka Konseptual}

Berdasarkan Kajian teori dan review artikel ilmiah, maka conceptual framework kajian pustaka dalam rangka membangun hipotesis adalah sebagai berikut:

1) Pengaruh atau hubungan faktor budaya terhadap persaingan pasar berdasarkan hasil riset: (Flammer, 2014), (Tjiharjadi, 2007) dan (Tian \& Borges, 2011)

2) Pengaruh atau hubungan faktor budaya terhadap pertumbuhan pasar berdasarkan hasil riset dari (Mukhtar et al., 2016), (Hafidz, 2018) dan (Tjiharjadi, 2007).

3) Pengaruh atau hubungan faktor sosial terhadap persaingan pasar berdasarkan hasil riset: (Flammer, 2014), (Yeni et al., 2019) dan (Ilhamalimy, 2020)

4) Pengaruh atau hubungan faktor sosial terhadap pertumbuhan pasar berdasarkan hasil riset dari (Yeni et al., 2019), (Setyadi \& Ali, 2017) dan (Chomvilailuk \& Butcher, 2014).

5) Pengaruh atau hubungan faktor personal terhadap persaingan pasar berdasarkan hasil riset: (Indarsin \& Ali, 2020), (Octavia \& Ali, 2017), (Suleman et al., 2020) dan (Asribestari \& Setyono, 2013).

6) Pengaruh atau hubungan faktor personal terhadap pertumbuhan pasar berdasarkan hasil riset dari (Mansur \& Buana, 2019), (Octavia \& Ali, 2017), (Indarsin \& Ali, 2020) dan (Asribestari \& Setyono, 2013).

7) Pengaruh atau hubungan persaingan pasar terhadap pertumbuhan pasar berdasarkan hasil riset dari (Hafidz, 2018), (Tjiharjadi, 2007), (Setyadi \& Ali, 2017) dan (Asribestari \& Setyono, 2013).

Dari rumusan masalah penulisan artikel ini dan kajian studi literature review baik dari buku dan artikel yang relevan, maka di perolah rerangka artikel ini seperti di bawah ini. 


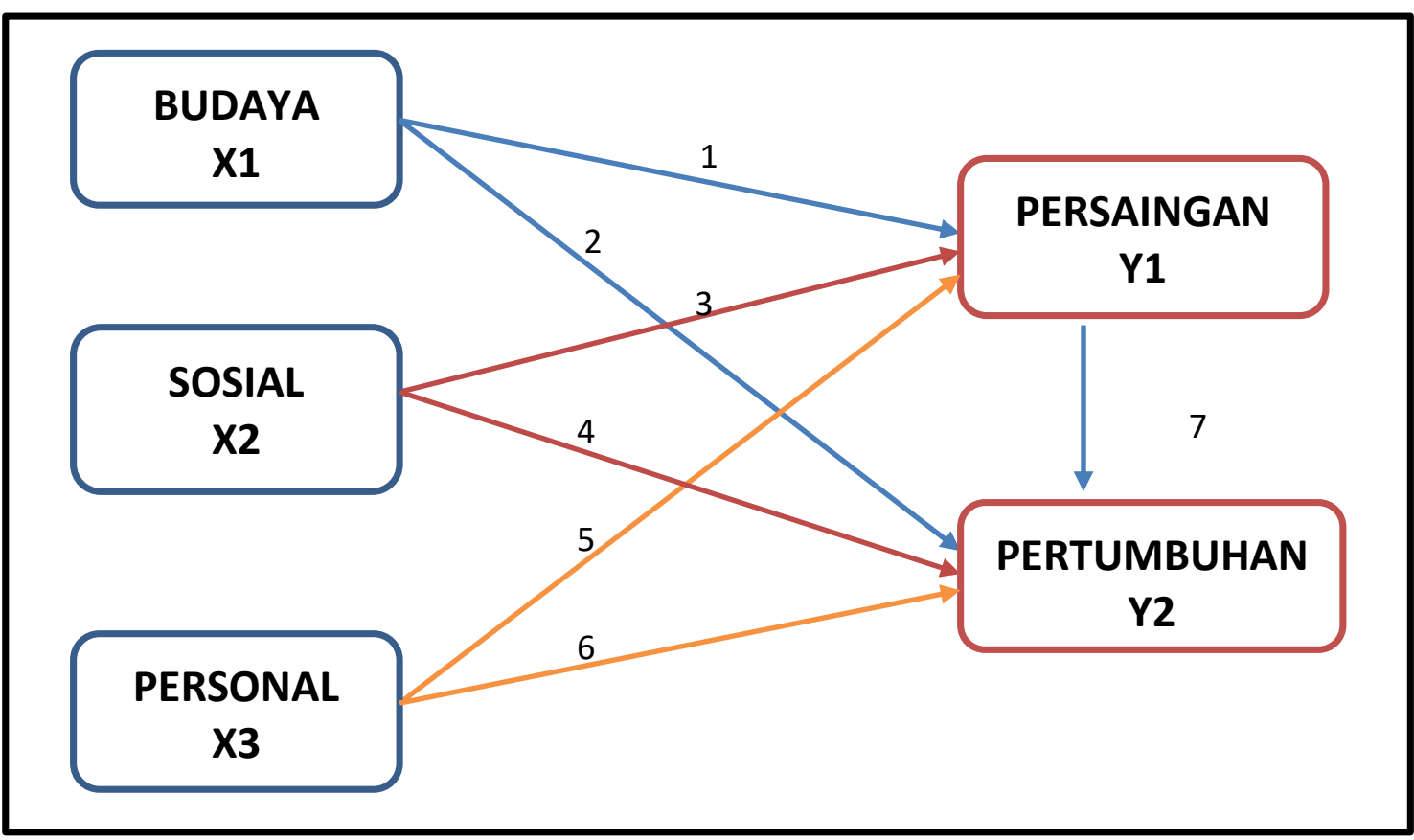

Gambar 1: Conceptual Framework

\section{KESIMPULAN DAN SARAN}

\section{Kesimpulan}

Berdasarkan rumusan artikel, hasil dan pembahasan yang di kaji dan di bahas pada artikel ini, maka dapat disimpulkan untuk membangun suatu hipoteis guna untuk riset selanjutnya adalah:

1. Faktor budaya memiliki hubungan dan berpengaruh terhadap persaingan pasar

2. Faktor sosial memiliki hubungan dan berpengaruh terhadap persaingan pasar

3. Faktor personal memiliki hubungan dan berpengaruh terhadap persaingan pasar

4. Faktor budaya memiliki hubungan dan berpengaruh terhadap pertumbuhan pasar

5. Faktor sosial memiliki hubungan dan berpengaruh terhadap pertumbuhan pasar

6. Faktor personal memiliki hubungan dan berpengaruh terhadap pertumbuhan pasar

7. Persaingan pasar memiliki hubungan dan berpengaruh terhadap pertumbuhan pasar

\section{Saran}

Bersdasarkan Kesimpulan di atas, maka saran pada artikel ini baik secara akademik atau secara empirik bahwa faktor budaya social dan personal memiliki keterkaitan dan pengaruh yang cukup besar terhadap pertumbuhan dan persaingan pasar, selain itu perlu di teliti lebih mendalam mengani sub dari masing - masing faktor tersebut agar bisa didapatkan sub faktor yang dominan yang berpengaruh. Oleh karena itu, masih di perlukan kajian yang lebih lanjut untuk melengkapi sub faktor - sub faktor lain apa sajakah yang dapat memepengaruhi pertumbuhan dan persaingan pasar. 


\section{Bibliography/Daftar Pustaka}

Ã, C. K. (2007). Industry product market competition and managerial incentives \$. 43, 275-297. https://doi.org/10.1016/j.jacceco.2007.02.004

Andersen, O., \& Suat, L. (1998). Resource-based theory and international growth strategies : an exploratory study. 7(0969), 163-184.

Asribestari, R., \& Setyono, J. (2013). PENGARUH DAYA TARIK PASAR TRADDISIONAL DAN PASAR MODERN TERHAD P PREFERENSI KONSUMEN. 2(3), 539-548.

Carman, J. M., \& Langeard, E. (1980). Growth Strategies for Service Firms. I(August 1979), 7 22.

Chen, X., Zou, H., \& Wang, D. T. (2009). Intern . J . of Research in Marketing How do new ventures grow? Firm capabilities, growth strategies and performance. International Journal of Research in Marketing, 26(4), 294-303.

https://doi.org/10.1016/j.ijresmar.2009.08.004

Chomvilailuk, R., \& Butcher, K. (2014). Social effects on unplanned in-store buying. Procedia Social and Behavioral Sciences, 148, 127-136.

https://doi.org/10.1016/j.sbspro.2014.07.026

Cronin, J. (1998). An Examination of the Relative Impact of Growth Strategies on Profit Performance.

Flammer, C. (2014). DOES PRODUCT MARKET COMPETITION FOSTER CORPORATE SOCIAL RESPONSIBILITY? EVIDENCE FROM TRADE LIBERALIZATION. March 2013. https://doi.org/10.1002/smj

Hafidz, M. (2018). PENGARUH FAKTOR BUDAYA DAN FAKTOR SOSIAL TERHADAP KEPUTUSAN PEMBELIAN PADA PT. PRUDENTIAL LIFE ASSURANCE Muhammad. 2(2), 245-260.

Ilhamalimy, R. (2020). DETERMINASI MINAT BELI ONLINE SHOPEE Ridho Rafqi Ilhamalimy 1) 1) Universitas Mercu Buana, Jakarta, Indonesia, . 2(1), 708-718. https://doi.org/10.31933/JIMT

Indarsin, T., \& Ali, H. (2020). Attitude toward Using m-Commerce: The Analysis of Perceived Usefulness, Perceived Ease of Use, and Perceived Trust : Case Study in Ikens Wholesale Trade , Jakarta - Indonesia. 6663, 995-1007. https://doi.org/10.21276/sjbms.2017.2.11.7

Kotler, P., \& Keller, K. L. (n.d.). Marketing Management.

Mansur, S., \& Buana, U. M. (2019). Impact of Customer Engagement to Reputation of the Bri Syariah Indonesia. May.

Mukhtar, P., Ali, P. H., \& Jannah, S. R. (2016). Analysis of Leadership Style and Oranizational Culture Effect on Career Development at Ministry Religious Affairs in Jambi Province. 18(11), 65-74. https://doi.org/10.9790/487X-1811046574

Octavia, A., \& Ali, H. (2017). The Model of Market Orientation, Entrepreneurial Orientation and Business Performance of Small and Medium Enterprises. 7(3), 331-337.

Schmidt, K. M. (1997). Managerial Incentives and Product Market Competition. 191-213.

Setyadi, A., \& Ali, H. (2017). Building Brand Image : Analysis of Service Quality and Customer Satisfaction. 770-777. https://doi.org/10.21276/sjbms

Suleman, D., Ali, H., Nusraningrum, D., \& Ali, M. M. (2020). Strategi Memenangkan 
Persaingan Bisnis Berbasis Perilaku Konsumen untuk Produk Fashion.

Tian, K., \& Borges, L. (2011). Cross-Cultural Issues in Marketing Communications : An Anthropological Perspective of International Business. 2(1), 110-126.

Tjiharjadi, S. (2007). Pentingnya posisi budaya dan efektivitas organisasi dalam kompetisi di masa depan. 6(2), 1-10.

Yeni, F., Erwin, G., \& Ali, H. (2019). ANALISIS STRATEGI PEMASARAN DALAM MENGHADAPI PERSAINGAN BISNIS PADA PT.FEDERAL INTERNASIONAL FINANCE (FIF) GROUP DI KECAMATAN IPUH, KABUPATEN MUKOMUKO. 1(September), 3854. https://doi.org/10.31933/JIMT 